\title{
Consumers' Purchasing Decisions for Confectionery and Savoury Snack Food Items on and off Promotion
}

\author{
Aimee McPoland \\ Undergraduate \\ Department of Hospitality and Tourism Management, Ulster University \\ Coleraine, Ireland \\ Dr. Sinéad Furey \\ Lecturer \\ Department of Hospitality and Tourism Management, Ulster University, \\ Coleraine, Ireland \\ Dr. Christopher McLaughlin \\ Lecturer \\ School of Business and Social Sciences, Institute of Technology Sligo \\ Sligo, Ireland
}

(c) Aimee McPoland, Sinéad Furey, Christopher McLaughlin. This work is licensed under the Creative Commons Attribution-NonCommercial-ShareAlike 4.0 International License. To view a copy of this license, visit https://creativecommons.org/licenses/by-nc-sa/4.0/ .

\begin{abstract}
Food retail outlets, by making food accessible, available and affordable, contribute significantly to consumers' food choices, including snack food choices, and ultimately their longer-term health status. Therefore, the food retail environment may represent an opportune place to harness marketing power to implement anti-obesity measures. The study aimed to understand consumers' purchasing decisions for confectionery and savoury snack food items both on and off promotion. Associated objectives sought to identify what influences consumers' food buying decisions and understand if these differ by food product category or promotional status, particularly in respect of single versus multi-pack confectionery/savoury snack food items, to inform retail promotional strategies and anti-obesity policymaking. In order to gain an insight into consumers' motivations, attitudes and behaviours, an ethically compliant, quantitative survey was designed which collected data from 302 respondents aged 18-75. Three-quarters (76\%) of those surveyed believed promotions are more prevalent for less healthy foods compared to healthy foods. Promotions were found to have a significant impact on consumer behaviour, causing $64 \%$ to purchase greater volume of an item and $76.5 \%$ to purchase confectionery and savoury snacks more readily. Respondents made unintended purchases regularly with the highest incidence among those shopping four to six times per week, while $72 \%$ of all unintended purchases were attributed to promotional activity. Findings highlight the clear effect promotions have on consumers' buying behaviour. The main enabler reported to encourage consumers to make healthier food choices was "if healthy food was cheaper". Additionally, the findings also suggest that increasing the price of less healthy foods (such as confectionery and savoury snacks) could also impact positively on consumers' purchasing behaviours. The research indicates the potential for future supermarket health
\end{abstract}


promotion initiatives to encourage consumers to make healthier food choices which could play a vital role in improving public health and subsequently reduce obesity levels.

Keywords: Retail Food Promotions; Healthy; Less Healthy; Savoury Snack; Confectionery.

\section{Introduction}

There has been increased interest/research effort surrounding the role of food environments in contributing to consumers' food choice (Young et al., 2016). As stated by Vandevijvere et al. (2018, p.1) 'Food environments are the collective, economic, policy and social surroundings, opportunities and conditions that influence people's food and beverage choices and nutritional status". This increasing attention is warranted given the stark rise in obesity levels which according to the Organisation for Economic Co-operation and Development (2017) are set to continually rise until 2030. Additionally, Butland et al. (2007) predicts by 2050 obesity at a global rate will affect $60 \%$ of men, $50 \%$ of women and $25 \%$ of children. In particular there is concern surrounding food retail promotions and their effect on consumers' food choices as Stones (2013) suggests that promotional activities tempt shoppers to buy more food than they need, and therefore helps to fuel obesity. The purpose of this paper is to understand how purchasing behaviour differs for confectionery food items on and off promotion. Although there is sufficient research to indicate that the presence of promotions has a short-term impact on the sales of a promoted item (Ailawadi et al., 2009), there is little research on consumers' attitudes towards promotions and understanding of what motivates consumers to purchase certain promotional items. The overall aim of this study was informed by an online, self-completed questionnaire. The research suggested evidence-informed conclusions and recommendations to inform potential retail interventions which could be adopted across the UK to improve food choice and, as a result, prevent obesity.

\section{Factors influencing food choice}

Obesity is the biggest public health crisis facing the United Kingdom (UK) today (Academy of Medical Royal Colleges, 2013, p. 3). It is a major risk factor for noncommunicable diseases such as diabetes, heart disease and cancer, significant disability and premature death (Ofei, 2005). The World Health Organisation has predicted that almost three-quarters of men and two-thirds of women in the UK will be overweight or obese in 15 years' time (Meikle, 2015). A change in diet and lifestyle has contributed to the worldwide obesity epidemic; individuals have increased their caloric consumption from food coupled with reduced energy expenditure in today's increasingly sedentary environment (Hill, Wyatt and Peters, 2012). Furthermore, there has been a shift from the traditional three meals per day norm towards a habit of snacking and grazing, in addition to an increased demand for convenience food (Bevis, 2012). Chu (2016) suggests that the increased reliance on convenience food may be explained by a shift in traditional gender roles that has resulted in an increase in women working, along with a decline in home cooking skills. These factors combined with other environmental factors such as increasing portion sizes, ease of accessibility to energy-dense foods, affordable price of calorific food, prevalent advertisements and promotions have been cited as the main drivers of the current obesity epidemic (Nederkoorn, 2014). 
The economic environment has a significant impact on consumers' food choices. Dennis (2015) states that consumers are becoming more promotion-sensitive with shoppers citing an increased cost of living and increased cost of food as the main drivers to seek out promotions. Inflation and tight budgets have led to consumers trading down to less expensive brands (Research, A.M, 2015). A study of Irish consumers reported a rise in shoppers trading down to cheaper brands from $39 \%$ in 2014 to $42 \%$ in 2015 in a bid to save some extra cash (Anon, 2015). According to Wynne-Jones (2015, p.79) "It is now easier than ever for consumers to 'trade down' due to the rise of discounters".

The rise of discounter stores is evident when analysing Gale (2018), who states that Aldi and Lidl have a combined growth of $80 \%$ since mid-2013. As Falck (2017, p.92) states, "these discounter stores rely on everyday low prices as well as aggressive price promotions to excite and attract customers". The continuous success of these stores indicates a demand for low prices and promotions and is further highlighted by Price (2013) who reveals that more than seven in ten Britons report that they like the thrill of getting a bargain. Likewise, customers reported that store offers are a major aspect in attracting them to a store (Goswami and Mishra, 2009).

\section{Price promotions}

Price promotions are used to boost sales by reducing the price of products as well as attempting to stimulate impulsive purchases by increasing the prominence of items in stores (Nakamura et al., 2015). This can be achieved through the use of tags and product placement to create a visually attractive display in a convenient location which can enhance consumption and customer satisfaction (Aloysius and Binu, 2017). Promotions include coupons, price reductions, bulk discounts and standalone offers which according to Smith et al. (2017 cited, Hawkes, 2009) incentivise consumers to purchase a food or beverage more quickly, more often and in greater volume.

The effects of price promotions are further explained by Ailawadi et al. (2009) who highlight that in addition to the substantial increase in sales of the promoted item, promotions in a store can have a 'halo' or a 'sales momentum' effect meaning the presence of a promotion in one category can also influence sales in other categories. Ailawadi et al. (2009 cited in Ailawadi et al., 2006) found that for every unit of gross promotion lift, 0.16 units of some other product are purchased elsewhere in the store. This research highlights not only the significant impact promotions can have on sales of the promoted item, but also how consumers can make unintended purchases because of in-store promotions on their purchasing behaviour. Not only can promotions result in consumers purchasing a larger volume of the promoted item or other unrelated items, they can also have an effect on brand loyalty. Sun, Neslin and Srinivassan (2003, p.389) highlight "it is a fundamental finding that promotions cause consumers to switch from Brand A to Brand B". Due to the increased cost of living, price is becoming a key factor in influencing purchasing decision and therefore the presence of promotions may be contributing to consumers becoming less brand loyal. Gammall (2015) reveals that shoppers now feel loyalty to just seven brands, down more than $50 \%$ compared to five years ago. As the grocery market responds to the demand for promotions and contends for shoppers' attention it is clear that promotions have become an ingrained part of the food retail environment (Price, 2013). 
The majority (59\%) of consumers in the Republic of Ireland (ROI) continue to look for savings on household expenses, which are above the EU average, and coping strategies include switching to grocery products that represent better value to them and actively seeking promotions (Collins, Kavanagh and George, 2012). An ROI study (Furey et al., 2019) provided an overview of the types of foods on price promotion in a sample of retail outlets in the ROI. The research concluded that more than one-third $(35 \%)$ of the total sample of food and drinks audited were categorised as high in fat, sugar and salt, a clear over-representation of their distribution in the food pyramid. In the UK consumer expenditure on price promotions is the highest in all of Europe, double that of countries such as Spain, France and Germany (Sparks and Burt, 2016). This highlights the significant role promotions play in the UK grocery market. Despite a misconception that promotions are more prevalent for less healthy foods, research by Hollywood et al. (2015) suggests that this is not the case. The Food Standards Agency research, which was conducted to determine the healthiness of food promotions using the Front of Pack Labelling system, found that nearly half $(47 \%)$ of all online food retail promotions were categorised as red (less healthy) while the remaining $53 \%$ were categorised as amber/green (healthy/moderately healthy). Findings by Hollywood et al. were further confirmed by similar research published in the American Journal of Clinical Nutrition, which also showed similar results stating, "on the whole less healthy items were no more frequently promoted than healthier ones" (Nakamura et al., 2019, p. 813).

Regardless of research confirming that less healthy foods are no more frequently promoted than healthy foods, McDonald and Milne (2016) found that discretionary foods such as savoury snacks and confectionery were more frequently purchased on promotion compared to the healthier categories such as fruit, vegetables and starchy carbohydrates (50\% versus 30\%). This research confirms that the increase caused by promotions is greater in the less healthy category. Yan et al. (2017) contend that price promotions have a stronger effect on less healthy foods due to consumers having less self-control and greater impulsive urges towards less healthy food. In contrast, Martin, Bauld and Angus (2017) suggest another reason for a greater uptake of promotions for less healthy food. They found that despite a balance of healthy and less healthy promotions, less healthy food promotions offer a greater reduction in price or a greater volume for a set cost compared to promotions for healthy food and drink products.

Although promotions are recognised as "an important tool in the marketing mix of food retailers" (Empen, Loy and Weiss, 2015 p.736), Nakamura et al. (2015, p. 808) express concern about some promotional activities stating "they may contribute to poor dietary choices and lure consumers away from healthier, higher priced options". According to Lawrence, Wallington and Lyons (2010, cited Hawkes, 2009) promotional messages encourage consumers to buy and eat more, and these messages contribute to the increasingly obesogenic environment.

\section{Obesogenic environment}

An obesogenic environment is defined by Lake and Townshend (2006, p.262) as "the sum of influences that the surroundings, opportunities, or conditions of life have on promoting obesity in individuals or populations". A study by Powell et al. (2016) into 
the frequency of promotions found that larger versus smaller product packages had significantly higher prevalence of price promotions activity. In supermarkets, promotions were more evident for family-size soda, orange and juice drinks than individual or regular sizes, and larger and family-size snack packages were promoted to a greater extent than smaller pack sizes. In a study of the Scottish retail market, McDonald and Milne (2016) had similar findings, reporting that promotions for less healthy foods were aimed at driving purchases ( $y$ for $£ x$ and multibuy) compared to the staple, healthier categories. It is evident promotions of less healthy food focuses on volume and as Powell et al. (2016) express such promotional activity can lead to an increase in consumption due to consumers stockpiling products on offer. Powell et al. (2016, p.107) state "the stockpiling of less healthy foods may prove to be problematic for public health when the food items are high in sugar, fat, or sodium." It is likely that purchasing a greater amount of a product can lead to overconsumption due to the convenience afforded by stockpiling. Therefore, if consumers are being influenced to buy less healthy food in bulk due to the presence of promotions, they are likely to overconsume, which can consequently have a negative effect on their health.

A change in the type of promotions may also be driving sales of less healthy foods as research by Mintel has reported that there has been a shift away from " $x$ for $y$ " promotions towards a focus on round pound deals (Price, 2013). Wilson (2016) has reported that on an all-Ireland basis, between 2017 and 2021, confectionery sales are expected to grow by $4.6 \%$. It was suggested that the reason for such a rise was due to increased multipack offers at supermarkets as they attempt to respond to the rise of discounter stores and retailers, such as Poundland, who are selling multipacks for $£ 1$, therefore contributing to the rise in chocolate sales.

It is no surprise that Brown (2017) found that more consumers are reaching for these sharing bags, as they are often better value and, as previously highlighted, consumers are seeking the best deal when filling their food basket due to macro and micro economic concerns. Cadbury has revealed confectionery is one of the most successful categories within the sector worth more than $£ 300$ million (Fleming, 2013) which is concerning considering the findings indicating consumers are not buying them to share. Morley (2018) reports that $22 \%$ eat the sharing bags alone, in one go, with the figure rising to $35 \%$ among 16 to 24 -year-olds. As Action on Sugar (2018) states, research carried out at Queen Mary University of London found that some "sharing" bags contained four times an adult's maximum daily sugar intake.

As Benson (2009, p.16) suggests, "the introduction of over-sized portions by the snack industry is aggravating obesity by encouraging over-consumption and promoting larger portions as a viable alternative to standard sizes". When these items are then promoted, consumers are encouraged to a greater extent. A Twitter poll carried out by Action on Sugar found that $85 \%$ of consumers agreed that price promotions on confectionery sharing bags should be banned (Smith, 2018). Furthermore, a professor of cardiovascular medicine responded to the news regarding the sugar content of sharing bags suggesting that companies were exploiting and manipulating consumers into buying these larger bags cheaply (Woodfield, 2018). This highlights civic and health professional support to tackle the issue, and it is interesting to learn that 
consumers have negative feelings towards such promotions which can easily influence them to purchase and subsequently result in overconsumption.

\section{Retail interventions to improve food choices}

As a result of the increasing burden of obesity and other diet-related chronic illnesses, this has prompted research into approaches to improve food choices among consumers. As Vandevijvere et al. (2018, p.971) state, "an important setting for potential intervention is the in-store retail food environment, defined as that which customers encounter when buying food, including the cost, quality, and availability of food". As Sparks and Burt (2016, p.3) state, "There is a need to understand the retail environment presented to customers in store as this drives consumers' decisions". Cameron et al. (2016) suggests using the four Ps of Marketing (Product, Price, Place and Promotion) as a useful structure for nutrition-related interventions in supermarkets.

\section{Price}

According to Andreyeva et al. (2010) the potential of price changes to improve food choices is evident from growing research on how relative food prices affect dietary quality and obesity, especially among those most at risk for obesity, younger consumers and lower income populations. Geliebter et al. (2013) conducted a study in Manhattan (USA) to establish how discounting low energy dense foods would affect consumers' purchasing, intake and body weight. The study found that between the discount group and the control group (who received no discounts) the discount group purchased and consumed significantly more fruit and vegetables over the eight weeks. After reflecting on the study during the baseline period, it was found that the discount group continued to purchase and consume more fruit and vegetables which indicates a sustained effect of the intervention. The results support Andreyeva et al. (2010) who previously discussed the potential benefits to consumers' diets by changing the price of food.

\section{Promotion}

Escaron et al. (2013) report that low-income populations purchase a high proportion of their food as prepared foods and from small stores, which has implications for intervention development. Stead et al. (2017) carried out a study to determine whether lowering prices and providing recipe suggestions for low income consumers was effective or not. The study targeted low-income consumers who live in disadvantaged postcode areas and used EPOS and customer membership data to identify consumers who had poor purchasing habits. These consumers were then targeted with price promotions and offered healthy eating advice and recipe suggestions, which were informed by their habits and preferences. Results from the study show how promotions combined with healthy eating advice and recipe suggestions have a modest, shortterm effect on low-income consumers and are feasible, although further approaches are needed to sustain such changes. As Glanz, Bader and lyer (2012) indicate, instore food marketing plays a key role in influencing consumers' food choices and warrants increased attention given the dramatic rise in obesity.

\section{Place}

Cameron et al. (2016 p.130) propose the impact of changing the healthiness of the supermarket environment is likely to be much greater than changing smaller outlets. 
This is likely due to supermarkets being the main source of readily available and accessible food for many consumers (Levy, 2010) as well as the 'Big Four' supermarkets accounting for two-thirds of the UK grocery market share (Kantar, 2018). One possible area in supermarkets which could be modified to encourage healthier food choices is at checkouts. Liberato, Bailie and Brimblecombe (2014, p.1) state: "Point-of-sale is a potentially important opportunity to promote healthy eating through nutrition education and environment modification".

Not only does the placement of less healthy products at the checkout promote healthy eating, it also appeals to consumers as Winkler et al. (2016) identified consumer concern and annoyance with placement and promotion of less healthy snacks, after an intervention to remove the less healthy snacks received positive feedback from consumers.

A study by Van Kleef (2012) into the impact of shelf assortment and arrangement of food at checkouts on consumer choice found that there was a higher probability of healthy snack choice when $75 \%$ of the assortment consisted of healthy snacks compared to conditions with $25 \%$ healthy snack assortments. The results are encouraging for other future strategies demonstrating how increasing the availability of healthy snacks and limiting the availability of less healthy snacks can promote sales and influence consumers to make better choices. Hollywood et al. (2016) also found that larger stores promoted a greater quantity of less healthy products in prominent locations and suggest that there is a strong potential for prominence to be used positively to encourage consumers to make better-informed choices. Furey et al. $(2019$, p.54) in the Irish context similarly recommends retailers "increase the frequency and prominence of healthy promotions in-store ... to encourage their uptake". It is clear that there is no easy way to tackle the obesity crisis but, as suggested by Davies (2016), if retailers recognised their role and helped by ensuring promotions and promotional activity did not encourage consumers to make less healthy food choices, progress could be made.

\section{Overall research aim}

The overall aim of this study is to understand consumers' purchasing decisions for confectionery and savoury snack food items on and off promotion. The associated objectives are:

- To describe both the frequency and consumer perceptions around food shopping and promotional offers;

- To understand further unplanned purchases of confectionery and savoury snacks;

- To examine the motivations for sharing/non-sharing bags of confectionery and savoury snacks; and

- To explore how price and promotional type influence consumers' healthy and less than healthy snack choices.

There has been considerable research conducted in the area of food promotions with a focus on prevalence, prominence and effect on sales. As highlighted by Ramathan (2010 cited in Hollywood et al., 2016, p.29) "most academic research focuses on how sales promotions affect aggregate sales of the promoted brand, and not on individual 
consumer responses to promotion." As the prevalence of price promotions has already been well documented by Powell et al., 2016 and other scholars, a survey was deemed the most appropriate data collection method.

\section{Methods}

The purpose of the survey is to gain an understanding of how food retail promotions affect consumers' purchasing decisions with a particular focus on confectionery and less healthy savoury snack foods. The survey will support the understanding of how purchasing behaviour differs for items on and off promotion and comprehend what motivates purchasing behaviour for less healthy snack items.

\section{Survey design and development}

The overall structure of the questionnaire was informed by an in-depth review of the literature to allow for comparisons to be drawn literature to allow for comparisons to be drawn and trends identified. In order to ensure the survey design met the overall research objectives a range of survey question types was utilised. The survey comprised three sections: Buyer habits to identify respondents' general buying habits such as frequency and location of shopping; a confectionery and savoury snacks section to identify how respondents viewed and responded to confectionery and snack food promotions; and demographics.

\section{Survey administration}

The questionnaire was piloted to collate feedback on any issues and make necessary changes to enhance the reliability of results for the final data collection. The quantitative data were collected using a self-completion questionnaire and distributed online using social media sites such as Facebook, Twitter and Linkedln, and through email. Using the Internet allows data to be collected from a large sample of people. As highlighted by Wright (2005), using the internet to conduct surveys has many benefits such as access to difficult to reach participants, convenience of having automated data collection, as well as reduced time and costs. A final sample of 302 respondents completed the survey.

\section{Data analysis}

The questionnaire responses were imported into SPSS (v24) to carry out analysis. Statistical analyses included frequencies reporting and Chi square tests (to measure statistical associations between variables such as age and gender). These analyses facilitated the comparison of how the different variables impacted on the research results.

\section{Ethical considerations}

Ethical permission was sought and granted from Ulster University Research Ethics Filter Committee. All respondents (aged 18-75) gave their informed consent to participate in the survey. Anonymity of the respondents was assured throughout by ensuring that no respondent was identifiable from their answers.

\section{Results}

\section{Demographics}

Table 1 shows the demographic breakdown of the respondents. The research aimed to gather data from a range of respondents aged 18-75, although as can be seen in Table 1 consumers aged 60-75 are underrepresented in the sample. This may be as 
a result of distributing the survey online and through social media as Statista $(2018 \mathrm{a}$, $2018 b)$ indicates only $17 \%$ of UK Facebook users were aged $55+$, while UK Twitter users aged $55+$ accounted $11 \%$ of users.

Table 1: Demographic breakdown of the sample

\begin{tabular}{ll}
\hline Demographic & \% of Respondents \\
\hline Age & $18-24-29 \%$ \\
& $25-39-35 \%$ \\
& $40-59-33 \%$ \\
Gender & $60-75-3 \%$ \\
& Male $-28 \%$ \\
& Female - 71\% \\
Employment Status & Full time job - 61\% \\
& Full time student - 18\% \\
& Part time job - 13\% \\
& Part time student - 1\% \\
& Retired -3\% \\
& Unemployed - 4\% \\
\hline
\end{tabular}

\section{Frequency of shopping}

It is clear from Figure 1 that respondents shop frequently, with half $(51 \%)$ of consumers visiting a shop/supermarket between two and three times per week. Additionally, onethird visit a food retailer more frequently; almost a quarter (24\%) shop for food between four and six times per week, and $9 \%$ report visiting a shop or supermarket daily. No differences in shopping frequency for age or gender were discovered. 


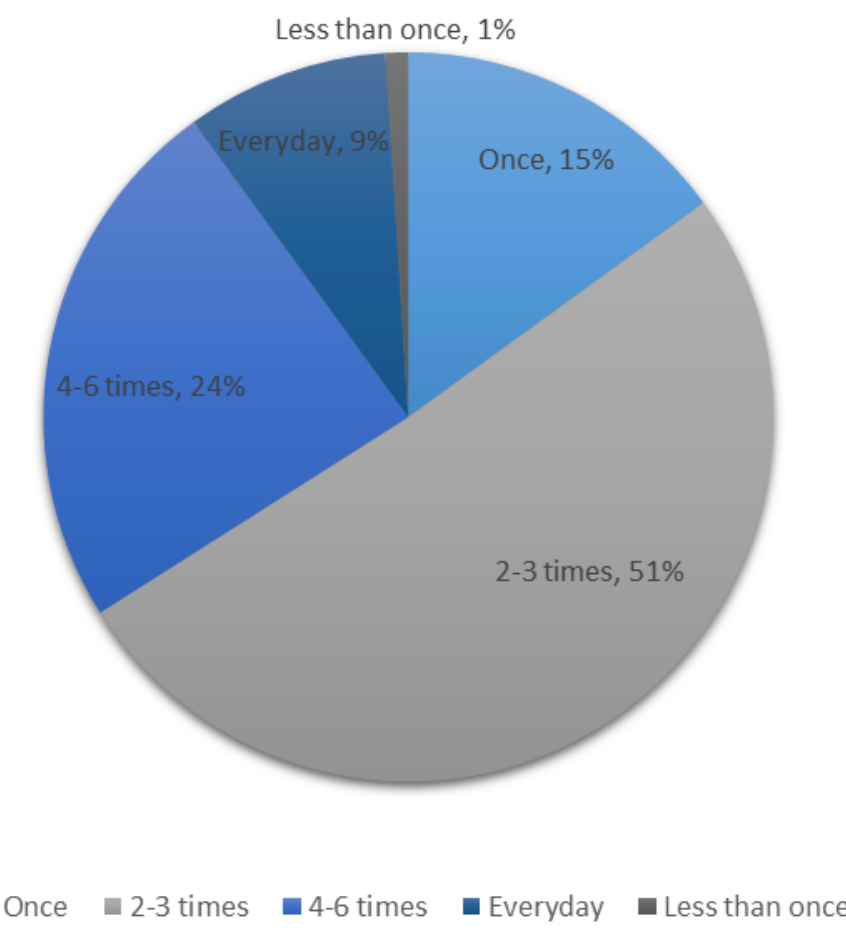

Figure 1: Frequency of shopping among respondents

\section{Perception of promotions}

When asked about the balance of healthy and less healthy promotions, $76 \%$ of respondents reported that they thought promotions were more prevalent for less healthy foods. This is important given that the majority (84\%) are visiting a shop at least twice per week and therefore observing promotional activity often. Only $15 \%$ felt that promotions were balanced, while $3 \%$ thought that healthy foods were promoted to a greater extent, and the remaining $6 \%$ were unsure. Although no statistically significant difference was observed, it was interesting to note a difference among males and females. Males were more likely than their female counterparts to report they did not know whether promotions were more prevalent for healthy or less healthy food ( $12 \%$ versus $3 \%$ respectively).

\section{Unplanned purchases of confectionery and savoury snacks}

Almost one-quarter $(24 \%)$ of respondents surveyed make unplanned purchases of confectionery or savoury snacks every time they visit a shop or supermarket, while $28 \%$ of respondents make unplanned purchases 'often' and a further $41 \%$ 'fairly often'. As already identified, those shopping frequently outnumber those shopping once per week or less. Even though no statistically significant difference was observed, results found that unplanned purchases of less healthy foods were more prevalent among those shopping four to six times per week, compared to other shopping frequencies. The same cohort was also most likely to make an unplanned purchase every time they visited a shop (18\%) compared to only $10 \%$ of daily shoppers making unplanned purchases on every occasion. Although it is unknown if unplanned purchases are a direct result of promotions, $36 \%$ of respondents agreed that special offers dictated the content of their shopping basket. Almost half $(45 \%)$ of respondents reported purchasing share bags 'often', and a further 35\% reported purchasing them 
'sometimes'. Among respondents, 'better value' was the main reason for purchasing share bags for over half of consumers (51\%), while an additional $30 \%$ cited 'sharing with family' as the reason for buying sharing bags.

\section{Sharing bags of confectionery and savoury snacks}

The research presented concerning results that $21 \%$ of consumers reported eating sharing bags of confectionery/savoury snacks in one go, while $14 \%$ said they ate them throughout the day (Figure 2 refers).

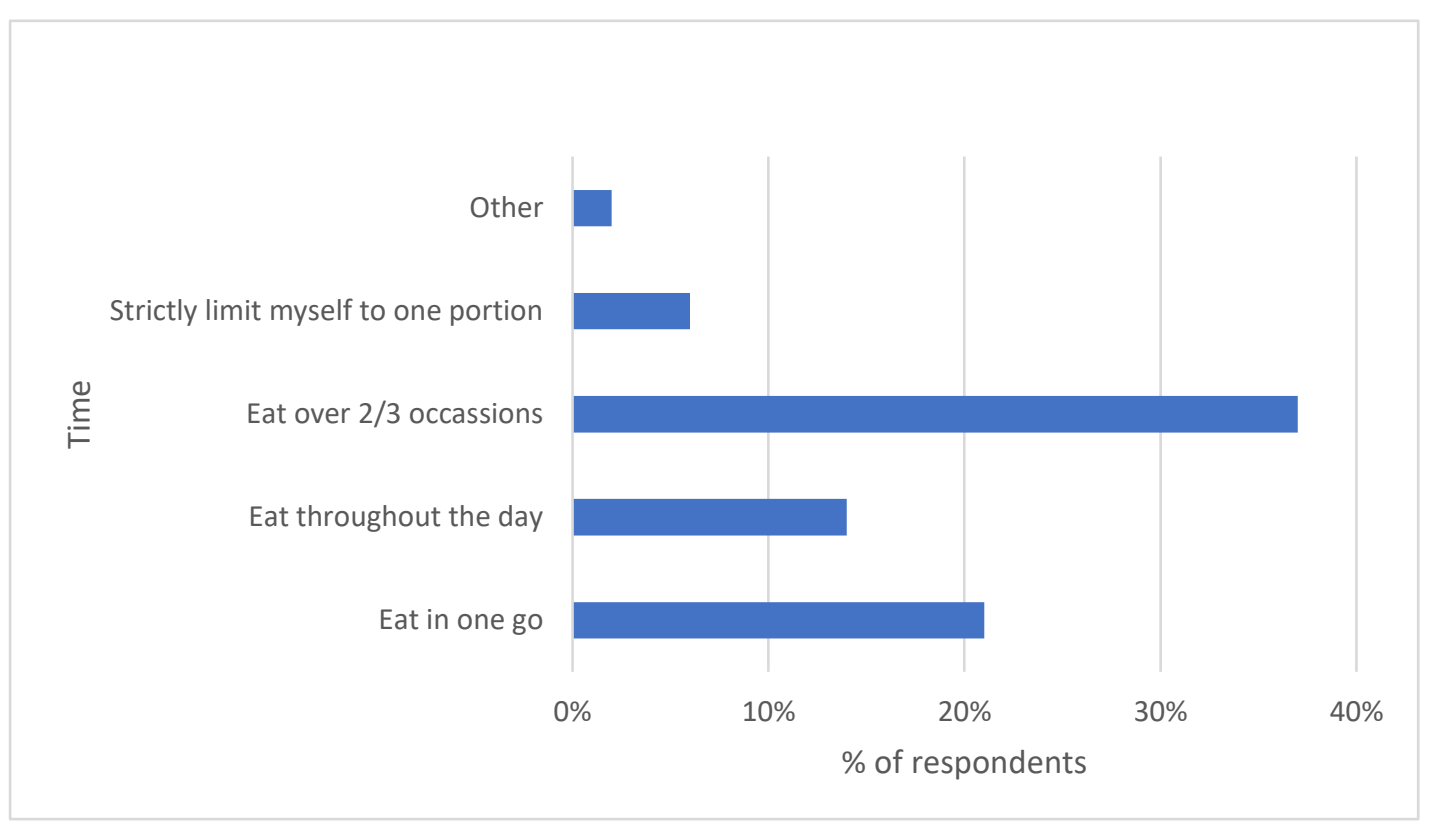

Figure 2: Time taken to consume sharing bags

As appreciable from Table 2, a substantial proportion of respondents reported eating sharing bags in a single sitting. An exception exists for those in the 60-75 age category, which may be explained by the lower response rate from this demographic. However, a clear trend has emerged that those aged 18-24 are more predisposed than their older counterparts to eat share bags in a single serving.

Table 2: Demographic breakdown of age versus time taken to consume share bags

\section{Time taken to consume sharing} bags

Eat in one go

\section{Age (years)}

18-24 $\quad 25-39 \quad 40-59 \quad 60-75$


Aimee McPoland, Sinéad Furey and Christopher McLaughlin

\begin{tabular}{|c|c|c|c|c|}
\hline $\begin{array}{l}\text { Eat throughout the } \\
\text { day }\end{array}$ & $36 \%$ & $43 \%$ & $21 \%$ & $0 \%$ \\
\hline $\begin{array}{l}\text { Eat over } 2 / 3 \\
\text { occasions }\end{array}$ & $26 \%$ & $36 \%$ & $36 \%$ & $2 \%$ \\
\hline $\begin{array}{l}\text { Strictly limit myself } \\
\text { to one portion }\end{array}$ & $35 \%$ & $52 \%$ & $12 \%$ & $0 \%$ \\
\hline
\end{tabular}

Findings also found that $16 \%$ reported the reason for buying these bags was due to habit; $74 \%$ of respondents reported that promotions encourage them to purchase confectionery and savoury snacks more readily; and 64\% of respondents purchased a greater volume of items on promotion. Furthermore, a greater percentage of those purchasing due to habit were aged 18-24, the same sub-group that is more likely to consume these bags in a single sitting.

\section{Preference for type of promotion}

Although many respondents reported that they purchased a greater volume of items due to the presence of promotions, the research found that for both healthy (64\%) and less healthy foods (62\%) consumers preferred price reductions. It was particularly interesting to note a difference, however marginal, for consumer preference for bulk buy promotions i.e. "Buy One Get One Free" with 35\% preferring this type of promotion for healthy foods and $39 \%$ preferring it for less healthy foods.

\section{Importance of price}

It is clear that consumers regard price as important, given that price reductions were the most appealing form of promotion. The research also revealed that more than half $(53 \%)$ of respondents agreed that price was the most important factor to them. The results also highlight how the majority of respondents (78\%) were of the opinion that healthy food is more expensive than less healthy food. In contrast, only $4 \%$ thought that healthy food was less expensive than less healthy food, and a further $16 \%$ believed there was no difference. These findings - combined with the fact that the majority of consumers think promotions are more prevalent for less healthy foods could have implications for their dietary choices, particularly as $66 \%$ of respondents report that they would purchase more healthy food if it were cheaper.

In contrast, respondents were asked if confectionery were more expensive would it change their purchasing behaviour. Figure 3 highlights respondents' estimated spend on confectionery and savoury snacks per week. 


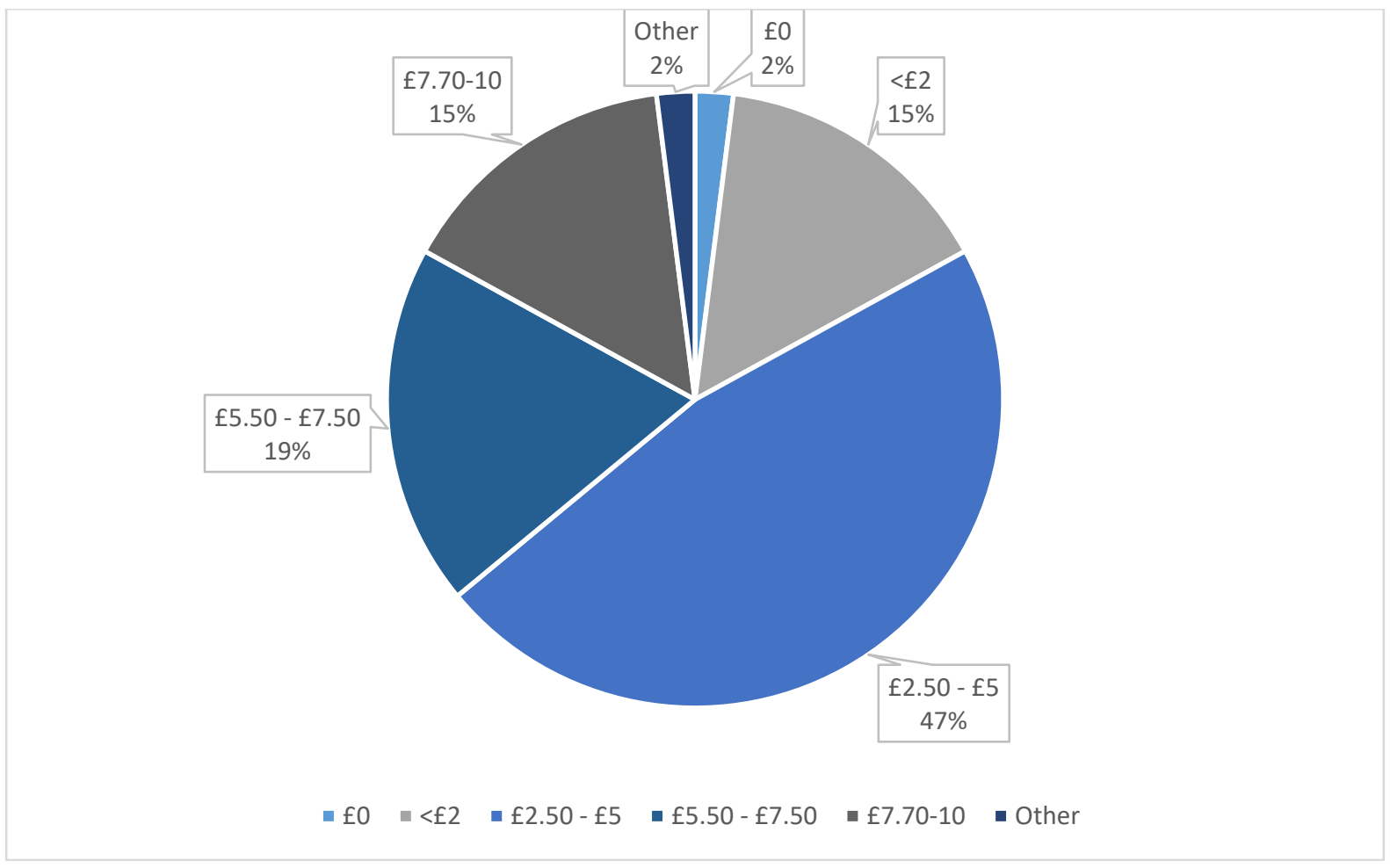

Figure 3: Consumer spend on confectionery per week

Three-fifths (61\%) agreed to some degree that it would affect their purchasing behaviours while $26 \%$ disagreed. These findings move beyond recounting the benefits of making healthy food cheaper but also making less healthy food more expensive. However a clear trend emerged indicating those who spend more on confectionery ( $£ 7.50$ - £10) per week, were less likely to think increasing the price would affect their purchasing behaviour (Phi $=0.325, \mathrm{p}<.05$ ). Respondents' spending on confectionery and savoury snacks on promotion per week can be seen in Figure 3. Almost half (47\%) spend between $£ 2.50$ and $£ 5.00$ while $34 \%$ spend between $£ 5.50$ and $£ 10$. It should be noted that these results only refer to promotional spend and therefore are likely to be higher including non-promotional purchases.

\section{Factors influencing healthy food choices}

The research confirms the purposeful positioning of nutritional food products as a potentially beneficial way to support consumers to make healthier choices as a third $(34 \%)$ of respondents reported that if promotions were more prominent for healthier food it would result in them making healthier choices. Making the in-store environment more healthful could also include the less-prominent positioning of less healthy food items. Results from the study showed that placing less healthy snack foods at the till caused $12 \%$ of respondents to make unintended purchases of confectionery. Therefore, by replacing these items with healthier alternatives, it may improve food choice. 
Figure 4 depicts the factors that would be more likely to encourage consumers to make healthier food choices. As established previously, price is a key factor, but it is also evident that convenience is regarded as important, given that meal suggestions (38\%), a greater shelf life $(37 \%)$ and increased prominence $(35 \%)$ were the most popular options after price.

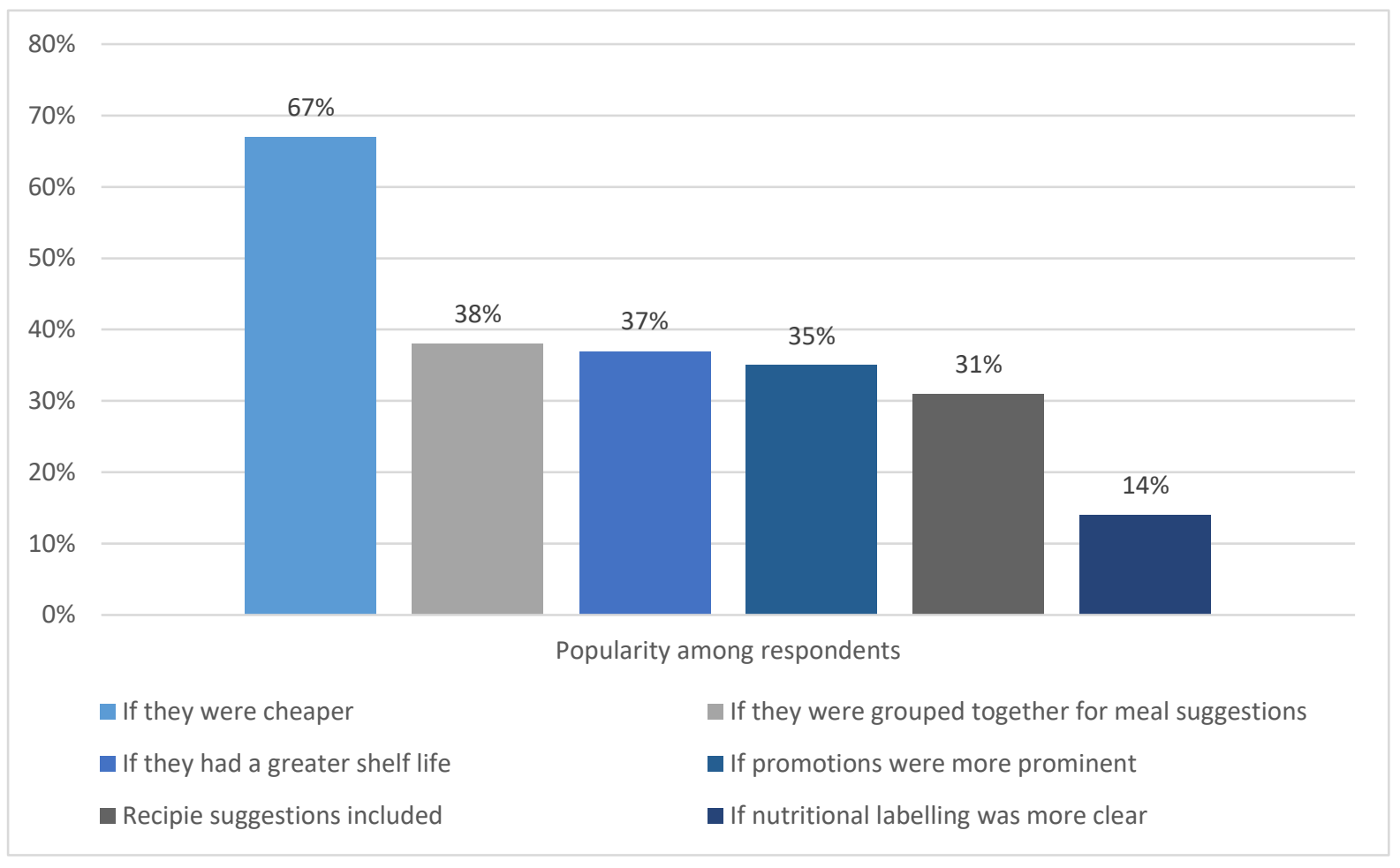

Figure 4: Factors which would encourage consumers to make healthier choices

\section{Demographic considerations}

A series of chi-square tests for independence was conducted. There were some statistical differences between variables which have been discussed throughout although, from the research, it can be determined that promotions have a similar effect on those of different ages, gender and occupation. Table 3 below outlines the tests conducted regarding key themes in the research. Findings indicated that there was only one significant associated reported between variables. Age was statistically associated with whether the individuals bought larger packs of confectionery; with those from older age groups more likely to state 'no' to buying larger packs of confectionery than what would have been statistically expected $\left(X^{2}(6)=14.727, p<\right.$ .05). However, in general, it was observed that most respondents did state 'sometimes' or 'yes' to buying larger packs of confectionery. Overall, demographic associations with each of the main perceptions failed to yielder any significant association, suggesting that the perceptions they hold about snacks, their promotion, purchasing or size is not dependent on their gender or education. 
Table 3: Associations between background factors and perceptions

\begin{tabular}{lcccc}
\hline & $\begin{array}{c}\text { Perception of } \\
\text { healthfulness } \\
\text { of promotions }\end{array}$ & $\begin{array}{c}\text { Frequency of } \\
\text { unplanned } \\
\text { purchases }\end{array}$ & $\begin{array}{c}\text { Consumption of } \\
\text { share bags of } \\
\text { confectionery/ } \\
\text { savoury snacks }\end{array}$ & $\begin{array}{c}\text { Do you buy } \\
\text { larger packs of } \\
\text { confectionery }\end{array}$ \\
\hline Gender & $\mathrm{X}^{2}(302,2)=$ & $\mathrm{X}^{2}(302,4)=$ & $\mathrm{X}^{2}(302,7)=$ & $\mathrm{X}^{2}(302,2)=$ \\
& 1.085 & 6.624 & 2.278 & 0.520 \\
Age & $\mathrm{Phi}=0.061$ & $\mathrm{Phi}=0.149$ & $\mathrm{Phi}=0.098$ & $\mathrm{Phi}=0.042$ \\
& $\mathrm{X}^{2}(302,6)=$ & $\mathrm{X}^{2}(302,12)=$ & $\mathrm{X}^{2}(302,21)=$ & $\mathrm{X}^{2}(302,6)=$ \\
& 7.855 & 17.447 & 17.121 & 14.727 \\
Occupation & $\mathrm{Phi}=0.249$ & $\mathrm{Phi}=0.241$ & $\mathrm{Phi}=0.155$ & $\mathrm{Phi}=0.221^{*}$ \\
& $\mathrm{X}^{2}(302,10)=$ & $\mathrm{X}^{2}(302,20)=$ & $\mathrm{X}^{2}(302,35)=$ & $\mathrm{X}^{2}(302,10)=$ \\
& 7.172 & 19.987 & 36.817 & 10.337 \\
& $\mathrm{Phi}=0.709$ & $\mathrm{Phi}=0.258$ & $\mathrm{Phi}=0.394$ & $\mathrm{Phi}=0.188$ \\
\hline
\end{tabular}

Note: ${ }^{*}=p<.05$

\section{Discussion}

\section{Frequency of shopping}

The results regarding respondents' frequency of shopping for food are noteworthy in terms of how often consumers are exposed to the retail environment and therefore subject to promotions and promotional activity. The findings correlate with Hope (2014) who suggests that the era of the once-a-week 'big' shop is nearing an end, as consumers now shop more frequently. The fact that there was no gender difference among respondents in respect of their shopping frequency may be as a result of households moving towards a shared shopper paradigm (Skrovan, 2017). According to Sandberg (2016), a higher prevalence of households sharing the responsibility of food shopping is due to factors such as an increase in working women.

\section{Perception of promotions}

Despite Hollywood et al. (2016), Nakamura et al. (2015) and Albright (2015) confirming a balance among healthy and less healthy promotions, it is interesting to discover consumers' perceptions on the healthfulness of promotions being skewed more prevalently towards less healthy food items. The observance of a greater percentage of males reporting they were unsure about the balance of promotions may be explained by Mortimer and Clarke (2011), who find males take less time to shop and are less likely to comparison shop for the best deal and therefore they may be less observant of promotions and the retail environment.

A disparate view also appears in the literature: Martin, Bauld and Angus (2017, p.11) found "promotions offered on unhealthy foods on average gave a greater reduction in price or offered a greater product volume for a set cost than for healthier foods". Therefore, a greater discount/deal on less healthy foods compared to healthy foods may result in consumers acknowledging these promotions largely and explain the consensus of the respondents. 
In addition, consumers' perceptions of the healthfulness of promotions may be due to promotional activity of less healthy foods such as shelf space, signage or prominence within stores as findings by Hollywood et al.

(2016) propose larger stores promote a greater quantity of less healthy products in prominent locations. Additionally, Ravensbergen et al. (2015) found that in Dutch supermarkets less healthy foods were more frequently advertised than healthy foods through supermarket flyers. Therefore, such promotional activities could elucidate consumers' less healthy perception of promotions. The increased promotional activity for less healthy foods could also be partly attributed to sweets and confectionery remaining at the top of unplanned grocery purchases in the UK (Glaberson, 2017).

\section{Unplanned purchases of confectionery and savoury snacks}

According to Rudi and Cakir (2017), a higher shopping frequency leads to less healthful food purchase due to factors such as product placement, prominence, shelf space and also due to consumers being less likely to have shopping lists for more frequent trips. It is therefore worrying to discover how often consumers are making unplanned purchases of less healthy foods. The frequency of unplanned confectionery and savoury snack purchases raises important questions regarding their consumption. It is likely that these unplanned purchases often feature larger sharing bags given the growing popularity of this format of confectionery and savoury snacks. Research confirms the demand for sharing bags as Nieburg (2016) reports that in convenience stores sales of these chocolate sharing bags increased by $8.7 \%$ driven by promotions while traditional single bars have declined slightly. Additionally, Randall (2020) reports that sharing bags of crisps now account for over a quarter (26\%) of the crisp market. The research finding that $80 \%$ of respondents 'sometimes' or 'often' bought sharing bags indicates an increase in this consumer behaviour, as Statista previously indicated (2014) that $46 \%$ of consumers said they did not buy share bags.

The reported increase in purchasing sharing bags occurs simultaneously to concerns in the literature about whether these large bags intended for sharing are actually shared. Yale University psychologist, Geier, describes them as another example of portion inflation (Fleming, 2013). While for consumers these share bags are often a more viable alternative to standard sizes (Benson, 2009), larger portion sizes can lead to overconsumption, a commonly cited factor of the current obesity crisis.

\section{Sharing bags of confectionery and savoury snacks}

The prevalence of solitary consumption of sharing bags uncovered by this research is supported by Morley (2018) who found that $22 \%$ eat sharing bags in one go with the figure rising to $35 \%$ among $16-24$ year olds. This may be due to a decrease in sensory specific satiety (SSS), as a study by Tey et al. (2012) concluded habitual consumption of high energy dense snacks results in a decrease in SSS which can ultimately lead to a higher energy intake of the snack. The consumption of sharing packs by individual consumers as a finding has important implications for public health as Action on Sugar (2018) report that certain chocolate confectionery sharing bags contain 29 teaspoons of sugar - which is four times an adult's reference nutrient intake. It is evident that sharing bag versions of confectionery and savoury snacks are facilitating 
overconsumption. Additionally, the presence of promotions for these items may have catastrophic effects on future public health by incentivising consumers to a greater extent or possibly increasing the volume purchased.

Potential exists for promotions to affect the volume of a food purchased, as Powell et al. (2016) propose that promotions are more prevalent for larger versus smaller packs and also have a higher level of promotional activity. Moreover, Powell et al. (2016) also expressed concern that promotions can lead to stockpiling and subsequently (over)consumption. As explained by Nakamura et al. (2015, p.813):

Products from less-healthy food categories are often non-perishable, whereas those from healthier food categories (in particular fruit and vegetables) are perishable. Therefore, stockpiling during a promotion may be more likely to happen for less-healthy food categories.

Therefore, the fact that almost two-thirds (64\%) purchased a greater volume of items on promotions may be concerning due to the fact consumers are more likely to stockpile less healthy foods. Furthermore, the stockpiling of foods can lead to an increase in consumption due to the easy accessibility to the consumer (Poelman et al., 2014).

\section{Preference for type of promotion}

Respondents' preference for price-based promotions contradicts Chandon and Wansink (2010, cited Mishra and Mishra, 2011) who suggest that consumers preferred price discounts for "vice foods" (less healthy foods) but preferred bonus packs to price discounts for virtue foods (healthy foods), thereby justifying price discounts for "vice foods".

\section{Importance of price}

This research highlighted how price may be a potential barrier to healthy eating for some consumers in agreement with research by Which? that found that $29 \%$ of shoppers reported finding it difficult to eat healthily as healthy food is more expensive than less healthy food (Quinn, 2016). The research suggests that intervening to make healthy food more affordable could have the potential to increase the healthfulness of consumers' purchases. Therefore, the findings suggesting that altering the price of confectionery could potentially lessen $61 \%$ of respondents' spend on confectionery and subsequently reduce consumption of these foods are extremely important.

Additionally, research by Julia et al. (2015) with regard to consumers' acceptance of a sugar tax for sweetened beverages in France found that $58 \%$ supported the sugar tax, perceiving it as helpful to improving the health of the population. Therefore, a sugar tax on confectionery could be a potential way to tackle the obesity issue and improve the diet and health of consumers.

\section{Factors influencing healthy food choices}

It is clear that in-store marketing plays a key role in influencing consumers' food choices (Glanz, Bader and lyer, 2012). Black et al., (2014) suggest that making instore environments more healthful, such as selling quality healthy food and placing 
them in prominent locations to prompt purchasing, could promote healthful food purchases. Equally, a study by Winkler et al. (2016) concluded how making checkouts healthier appeals to consumers.

\section{Limitations}

Although non-probability sampling was the most convenient way to gather responses, if more time and resources were to be allocated another method may have been more reliable. Stratified random sampling could have been used to ensure the entire population was represented equally. In addition, most respondents were in employment; it may have been useful to include a question regarding income. This would have allowed for analysis of how promotions affect those with higher or lower incomes.

\section{Conclusion}

On average across Western Europe, more than one-quarter of food and drink sales volume $(28.6 \%)$ is now sold on promotion (French, 2003). Price promotions have been shown to be extremely effective in altering consumer behaviour with a $200-1,000 \%$ uplift in product sales (Hamlin, Lindsay and Insch, 2012), albeit in the short-term (Jetter and Cassady, 2006). Promotional spend on confectionery was extremely high among respondents compared to figures from 2010 indicating $£ 1.22$ per person per week was spent on confectionery in the UK (DEFRA, 2020). Additionally, the frequency of unplanned purchases of less healthy foods was inflated among respondents, with $24 \%$ making unplanned purchases every time they visited a shop. This is concerning due to the number of times respondents reported shopping per week. The research also identified the popularity of sharing versions of confectionery and savoury snacks and associated consumption habits. The majority $(80 \%)$ of respondents reported they purchased sharing bags, with $21 \%$ consuming the entire bag in one sitting or throughout the course of a day (14\%). This is concerning given that some of these bags containing up to four times an adult's recommended daily sugar intake. The main reason cited for purchasing these larger bags was 'better value' which highlights the role price and promotions can play in food choice. Although promotions are not the solitary reason for consumers' purchasing products, they have a considerable impact as Hill (2016) estimates that once a product is placed on promotion $58 \%$ of sales are due to the offer, whereas $42 \%$ happen without the promotional incentive. The research concluded that price reductions were by far the most appealing form of promotion for both healthy and less healthy foods, which further indicates the role price plays in consumers' food choices.

From the findings it can be argued that promotions, especially for less healthy foods, can be a contributing factor to poor dietary choices and subsequently the development of obesity. Obesity is a complex, multifaceted condition that has no easy or obvious solution (Butland et al., 2007). However, the research has identified a number of potential interventions which may prove significant in preventing obesity and improving food choice among consumers. While more systematic research is needed to improve food choice and encourage healthier diets, the potential benefit of altering the price of food, shifting the balance of promotions from less healthy foods to healthy foods, and providing more convenience to consumers is promising. As Cameron et al. (2016) indicate, the nutrition environment of supermarkets has the potential to significantly 
influence the eating behaviour of populations. Therefore supermarkets and shops need to take steps to create healthier in-store environments as consumers do not require further incentivisation to purchase less healthy foods. These foods already have a strong appeal to consumers due to their nutrient composition and addictive nature.

Concretely, several recommendations can be suggested in order to facilitate healthier consumer choices in the food retail environment. Firstly, regarding the presence of promotions for less healthy foods: these foods should not be given prominence over healthy foods as consumers already find energy dense foods appealing and readily available throughout their shopping experience. Secondly, retailers should not be striving for a balance between healthy and less healthy food; they should be more ambitious in terms of contributing to the public health agenda and, as healthy food contributes more recommended nutrients than does less healthy food, therefore the retail environment should reflect and encourage this. Additionally, these healthy foods on promotions should be marketed in-store as meal suggestions to meet rising consumer demands for convenience and allow consumers to make healthy choices in an accessible, timely manner.

In conclusion, the research clearly identifies that consumers' purchasing behaviour is predominately price- and promotion-orientated as 36\% agreed that their shopping basket is dictated by offers while $55 \%$ agreed that price is the most important factor to them when shopping. The majority of consumers $(72 \%)$ purchase confectionery and savoury snacks more readily due to promotions as well as purchase a greater volume (64\%). There is a general consensus that healthy food is more expensive than less healthy food and in order to change eating behaviour among consumers reducing the price of healthy food is a potential solution as $67 \%$ of consumers believe that if healthy food was cheaper it would encourage them to eat more healthily.

Importantly, food retailers should be encouraged to recognise their corporate social responsibility and public health as well as profit obligations. Given their significance as the point of access for consumers' food choices, food retailers have an important role to play in making the healthier choice the easy choice for consumers.

\section{References}

Academy of Medical Royal Colleges. (2013) 'Measuring up: the medical profession's prescription for the nation's obesity crisis', Available at: http://www.aomrc.org.uk/wpcontent/uploads/2016/05/Measuring Up 0213.pdf (Accessed 12 February 2020).

Action on Sugar (2018) 'Call for a complete ban on all confectionery price promotions after new survey reveals shocking amounts of sugar'. Available from:

http://www.actiononsugar.org/news-centre/press-releases/2018/call-for-a-complete-ban-onall-confectionery-price-promotions-after-new-survey-reveals-shocking-amounts-of-sugar.html (Accessed: 2 March 2018).

Ailawadi, K.L., Beauchamp, J.P., Donthu, N., Gauri, D.K. and Shankar, V. (2009) 'Communication and promotion decisions in retailing: a review and directions for future 
research', Journal of Retailing, 85 (1), pp. 42-55. https://doi.org/10.1016/j.jretai.2008.11.002 (Accessed: 25 February 2018).

Aloysius, G. and Binu, D. (2013) 'An approach to products placement in supermarkets using PrefixSpan algorithm', Journal of King Saud University - Computer and Information

Sciences, 25(1), pp. 77-87. https://doi.org/10.1016/j.jksuci.2012.07.001. (Accessed: 2 March 2018).

Andreyeva, T., Long, M.W. and Brownell, K.D. (2010) 'The impact of food prices on consumption: a systematic review of research on the price elasticity of demand for food', American Journal of Public Health, 100 (2), pp. 216-222. doi: 10.2105/AJPH.2008.151415.

Anon (2015) 'The price is right', Checkout, 41(5), pp. 78-79. Business Source Complete, EBSCOhost [Online]. (Accessed: 2 March 2018).

Benson, C. (2009) 'Increasing portion size in Britain', Society, Biology and Human Affairs, 74(2), pp. 4-20.

Bevis, E. (2012) 'Home cooking and eating habits: global survey strategic analysis'. Available from: https://blog.euromonitor.com/2012/04/home-cooking-and-eating-habitsglobal-survey-strategic-analysis.html (Accessed: 25 February 2018).

Black, C., Ntani, G., Inskip, H., Cooper, C., Cummins, S., Moon, G. and Baird, J. (2014) 'Measuring the healthfulness of food retail stores: variations by store type and neighbourhood deprivation', International Journal of Behavioural Nutrition and Physical Activity, 11 (69). doi: 10.1186/1479-5868-11-69. (Accessed: 2 March 2018).

Brown, N. (2017) 'Guilty pleasures: how can sweets get the feel good factor?, The Grocer, 14 July [Online]. Available at:

https://www.thegrocer.co.uk/reports/digital-features/confectionery-report-2017/guiltypleasures-how-can-sweets-get-the-feel-good-factor/555220.article (Accessed: 8 March 2018).

Butland, B., Jebb, S., Kopelman, P., McPherson, K., Thomas, S., Mardell, J. and Parry, V. (2007) 'Tackling obesities: future choices', $2^{\text {nd }}$ edn. UK: Government Office for Science. Available at:

https://assets.publishing.service.gov.uk/government/uploads/system/uploads/attachment da ta/file/287937/07-1184x-tackling-obesities-future-choices-report.pdf (Accessed: 28 April 2018).

Cameron, A., Charlton, E., Ngan, W. and Sacks, G. (2016) 'A systematic review of the effectiveness of supermarket-based interventions involving product, promotion, or place on the healthiness of consumer purchases', Current Nutrition Reports, 5(3), pp. 129-138.

Chu, W. (2016) 'UK a nation of 'convenience food and waste,' says survey', Foodnavigator.com, 31 March [Online]. Available at:

https://www.foodnavigator.com/Article/2016/04/01/UK-a-nation-of-convenience-food-andwaste-says-survey (Accessed: 8 February 2018).

Collins, A., Kavanagh, E. and George R. (2012) 'Store deal prone shoppers: motivators and implications for the supply chain in a distressed market', The International Review of Retail, Distribution and Consumer Research, 22(1), pp. 83-100.

https://doi.org/10.1080/09593969.2011.634510 (Accessed: 20 December 2019). 
Davies, S. (2016) 'Should retailers do more to promote healthier food?', Which, 4 August [Online]. Available at:

https://conversation.which.co.uk/food-drink/more-supermarket-promotions-less-healthyfoods/ (Accessed: 6 March 2018).

DEFRA (2020) 'Weekly UK household expenditure on confectionery 2006-2017/2018', Statista. Available at:

https://www.statista.com/statistics/284313/weekly-household-expenditure-on-confectioneryin-the-united-kingdom-uk/ (Accessed: 12 February 2020).

Dennis, M. (2015) 'Christmas promotions to lure shoppers away from main supermarket, says new consumer survey' Talking Retail, 8 December 2015 [Online]. Available at: https://www.talkingretail.com/news/industry-news/christmas-promotions-lure-shoppers-awaymain-supermarket-says-new-consumer-survey-08-12-2015/ (Accessed: 10 February 2018).

Empen, J., Loy, J-P. and Weiss, C. (2015) 'Price promotions and brand loyalty: Empirical evidence for the German ready-to-eat cereal market', European Journal of Marketing, 49 (5/6), pp. 736-759. ProQuest Central, EBSCOhost [Online]. (Accessed: 10 February 2018).

Escaron, A.L., Meinen, A.M., Nitzke, S.A. and Martinez-Donate, A.P. (2013) Supermarket and grocery store-based interventions to promote healthful food choices and eating practices: a systematic review. Preventing Chronic Disease, 10, E50. doi: 10.5888/pcd10.120156. (Accessed: 28 February 2018).

Falck, M. (2017) 'Win the pricing war: retailers must understand the impact of pricing strategies beyond Every Day Low Price to stay competitive and increase profit margins both online and in-store', Retail Merchandiser, 57 (4), pp. 92-93.

Fleming, A. (2013) 'Chocolate bags: filled with calories', The Guardian, 29 May 2013 [Online]. Available at:

https://www.theguardian.com/lifeandstyle/2013/may/29/chocolate-bags-filled-with-calories (Accessed: 18 February 2018).

French, S. A. (2003) 'Pricing effects on food choices', The Journal of Nutrition, 133(3), pp. 841S-843S. doi: 10.1093/jn/133.3.841S.

Furey, S., McLaughlin, C., Hollywood, L.E., Burns, A., McMahon-Beattie, U., Price, R.K., Humphreys, P., McCarthy, M., Collins, A., Raats, M., Tatlow-Golden, M., Dean, M. and Murrin, C. (2019) 'What's on offer? The types of food and drink on price promotion in retail outlets in the Republic of Ireland'. Available at:

https://www.safefood.eu/SafeFood/media/SafeFoodLibrary/Documents/Publications/Researc h\%20Reports/Whats-on-offer.pdf. (Accessed: 6 January 2020).

Gale, A. (2018) 'Why Aldi and Lidl will keep on growing', Management Today, 1 May 2018 [Online]. Available at:

https://www.managementtoday.co.uk/why-aldi-lidl-will-keep-growing/article/1386497

(Accessed: 10 February 2018).

Gammall, K. (2015) 'More UK shoppers come to value the discounters', The Guardian, 28 September 2015 [Online]. Available at:

https://www.theguardian.com/money/2015/sep/28/more-uk-shoppers-come-to-value-thediscounters-aldi-lidl (Accessed: 11 February 2018). 
Geliebter, A., Ang, I.Y., Bernales-Korins, M., Hernandez, D., Ochner, C.N., Ungredda, T., Miller, R. and Kolbe, L. (2013) 'Supermarket discounts of low-energy density foods: effects on purchasing, food intake, and body weight', Obesity, 21(12), pp. E542-E548. ProQuest Central, EBSCOhost [Online]. (Accessed: 11 February 2018).

Glaberson, H. (2017) 'Confectionery still top for impulse buys, survey', Confectionery News, 14 March 2017 [Online]. Available at:

https://www.confectionerynews.com/Article/2011/06/16/Confectionery-still-top-for-impulsebuys-survey (Accessed: 23 February 2018).

Glanz, K., Bader, M.D.M. and lyer, S. (2012) 'Retail grocery store marketing strategies and obesity: an integrative review', American Journal of Preventive Medicine, 42(5), pp. 503-512. doi: 10.1016/j.amepre.2012.01.013. (Accessed: 11 February 2018).

Goswami, P. and Mishra, S. (2009) 'Would Indian consumers move from kirana stores to organized retailers when shopping for groceries?', Asia Pacific Journal of Marketing and Logistics, 21(1), pp. 127-143. ProQuest Central, EBSCOhost [Online]. (Accessed: 18 April 2018).

Hamlin, R. P., Lindsay, S. and Insch, A. (2012) 'Retailer branding of consumer sales promotions. A major development in food marketing?', Appetite, 58(1), pp. 256-264. doi: 10.1016/j.appet.2011.10.008.

Hawkes, C. (2009) 'Sales promotions and food consumption', Nutrition Reviews, 67(6), pp. 333-342. doi: 10.1111/j.1753-4887.2009.00206.x. (Accessed: 18 April 2018).

Hill, R. (2016) 'Have we reached peak supermarket promotion?', Kantar UK Insights, 1 December 2016 [Online]. Available at:

https://uk.kantar.com/consumer/shoppers/2016/understanding-supermarket-promotions/ (Accessed: 18 April 2018).

Hill, J.O., Wyatt, H.R. and Peters, J.C. (2012) 'Energy balance and obesity', Circulation, 126(1), pp. 126-132. doi: 10.1161/CIRCULATIONAHA.111.087213. Available at: https://www.ncbi.nlm.nih.gov/pmc/articles/PMC3401553/. (Accessed: 18 April 2018).

Hollywood, L., Furey, S., Burns, A., McMahon-Beattie, U., Price, R., Duffy, M., Dowler, E., Livingstone, B., Humphreys, P., Moore, C. and McCullagh, F. (2015) 'A three-stage investigation into the balance of healthy versus less healthy food promotions among Northern Ireland food retailers - final report to Food Standards Agency in Northern Ireland'. Available at::

https://www.food.gov.uk/sites/default/files/media/document/fs305021finalreportmarch15.pdf (Accessed: 12 December 2018).

Hope, K. (2014) 'The death of the weekly supermarket shop', BBC News, 5 October 2014 [Online]. Available at: http://www.bbc.co.uk/news/business-29442383 (Accessed: 12 March 2018).

Jetter, K. M. and Cassady, D. L. (2006) 'The availability and cost of healthier food alternatives', American Journal of Preventive Medicine, 30(1), pp. 38-44. doi: 10.1016/j.amepre.2005.08.039. 
Julia, C., Mejean, C., Vicari, F., Peneau, S. and Hercberg, S. (2015) 'Public perception and characteristics related to acceptance of the sugar-sweetened beverage taxation launched in France in 2012', Public Health Nutrition, 18(14), pp. 2679-2688. doi: 10.1017/S1368980014003231. (Accessed: 18 April 2018).

Kantar (2018) 'Grocery market share'. Available at:

https://www.kantarworldpanel.com/en/grocery-market-share/great-britain (Accessed: 27 April 2018).

Lake, A. and Townshend, T. (2006) 'Obesogenic environments: exploring the built and food environments', The Journal of the Royal Society for the Promotion of Health, 126(6), pp. 262-267. doi: 10.1177/1466424006070487. (Accessed: 25 April 2018).

Lawrence, G., Wallington, W. and Lyons, K. (2010) 'Supermarkets, food systems and public health', in: Lawrence, G., Wallington, W. and Lyons, K. (eds.) Food Security, Nutrition and Sustainability. London: Earthscan.

Levy, G. (2010) 'The supermarket as an environment for facilitating dietary behaviour change', Available at:

https://www.heartfoundation.org.au/images/uploads/publications/NHF-Supermarket-rapidreview-FINAL.pdf (Accessed: 25 April 2018).

Liberato, S.C., Bailie, R. and Brimblecombe, J. (2014) 'Nutrition interventions at point-of-sale to encourage healthier food purchasing: a systematic review', BMC Public Health, 14, pp. 114. Academic Search Complete, EBSCOhost [Online]. (Accessed: 27 April 2018).

Martin, L., Bauld, L. and Angus, K. (2017) 'Rapid evidence review: The impact of promotions on high fat, sugar and salt (HFSS) food and drink on consumer purchasing and consumption behaviour and the effectiveness of retail environment interventions'. Edinburgh: NHS Scotland. Available at:

http://www.healthscotland.scot/media/1611/rapid-evidence-review-restriction-of-pricepromotions.pdf (Accessed: 3 March 2018).

McDonald, A. and Milne, A. (2016) 'Foods and drinks purchased into the home in Scotland using data from Kantar WorldPanel'. Available at:

http://www.foodstandards.gov.scot/downloads/Food and Drinks Purchased into The Hom e in Scotland report.pdf (Accessed: 3 March 2018).

Meikle, J. (2015) 'Falling price of processed foods fuelling obesity crisis, says study', The Guardian, 11 May 2015 [Online]. Available at:

https://www.theguardian.com/society/2015/may/11/falling-price-processed-foods-obesitycrisis-tax (Accessed: 11 February 2018).

Morley, K. (2018) 'Calls for "sharing bags" of sweets to be banned because people eat them all in one go', The Telegraph, 26 January 2018. Available at:

http://www.telegraph.co.uk/news/2018/01/26/calls-sharing-bags-sweets-banned-people-eatone-go/ (Accessed: 7 February 2018).

Mortimer, G. and Clarke, P. (2011) 'Supermarket consumers and gender differences relating to their perceived importance levels of store characteristics', Journal of Retailing and Consumer Services, 18(6), pp. 575-585. https://doi.org/10.1016/j.jretconser.2011.08.007 (Accessed: 11 February 2018). 
Nakamura, R., Suhrcke, M., Jebb, S.A., Pechey, R., Almiron-Roig, E. and Marteau, T.M. (2015) 'Price promotions on healthier compared with less healthy foods: a hierarchical regression analysis of the impact on sales and social patterning of responses to promotions in Great Britain', The American Journal of Clinical Nutrition, 101(4), pp. 808-816. Available at: https://www.ncbi.nlm.nih.gov/pmc/articles/PMC4381774/pdf/ajcn094227.pdf (Accessed: 7 February 2018).

Nederkoorn, C. (2014) 'Effects of sales promotions, weight status, and impulsivity on purchases in a supermarket', Obesity (Silver Spring), 22(5), pp. E2-E5. doi: 10.1002/oby.20621. (Accessed: 3 March 2018).

Nieburg, O. (2016) 'Galaxy and Maltesers gain ground on Cadbury Dairy Milk as top UK cstore chocolates, finds IRI', Confectionery News, 12 January 2016 [Online]. Available at: https://www.confectionerynews.com/Article/2015/11/04/Bestselling-UK-chocolate-bars-IRIconvenience-store-analysis (Accessed: 4 April 2018).

Odoms-Young, A., Singleton, C.R., Springfield, S., McNabb, L. and Thompson, T. (2016) 'Retail environments as a venue for obesity prevention', Current Obesity Reports, 5(2), pp. 184-191. Available at: https://www.ncbi.nlm.nih.gov/pmc/articles/PMC5508978/ (Accessed: 21 February 2018).

Organisation for Economic Co-operation and Development. (2017) 'Obesity update: 2017', Available at: https://www.oecd.org/els/health-systems/Obesity-Update-2017.pdf (Accessed: 28 April 2018).

Ofei, F. (2005) 'Obesity - a preventable disease', Ghana Medical Journal, 39(3), pp. 98-101. Available at: https://www.ncbi.nlm.nih.gov/pmc/articles/PMC1790820/pdf/GMJ3903-0098.pdf (Accessed: 7 February 2018).

Poelman, M.P., de Vet, E., Velema, E., Seidell, J.C. and Steenhuis, I.H.M. (2014) 'Behavioural strategies to control the amount of food selected and consumed', Appetite, 72, pp. 156-165. Available at:

http://www.sciencedirect.com/science/article/pii/S0195666313003978 (Accessed: 7 February 2018).

Powell, L.M., Kumanyika, S.K., Isgor, Z., Rimkus, L., Zenk, S.N. and Chaloupka, F.J. (2016) 'Price promotions for food and beverage products in a nationwide sample of food stores', Preventive Medicine, 86, pp. 106-113. doi: 10.1016/j.ypmed.2016.01.011 (Accessed: 6 February 2018).

Price, A. (2013) 'Attitudes towards pricing and promotions in food and drink - UK - April 2013', Mintel reports platform, UK series. Available from: http://academic.mintel.com/display/638017/ (Accessed: 6 February 2018).

Quinn, I. (2016) 'Unhealthy foods 'at heart of supermarket promotions", The Grocer, 4 August 2016. Available at: https://www.thegrocer.co.uk/health/unhealthy-foods-at-heartof-supermarket-promotions/540161.article (Accessed: 6 February 2018).

Randall, G. (2020) Potato crisps bag top savoury snack. Warwickshire: Agriculture and Horticulture Development Board. Available at: https://ahdb.org.uk/news/consumer-insightpotato-crisps-bag-top-savoury-snack (Accessed: 12 February 2020). 
Ravensbergen E.A., Waterlander, W.E., Kroeze, W. and Steenhuis, I.H. (2015) 'Healthy or unhealthy on sale? A cross-sectional study on the proportion of healthy and unhealthy foods promoted through flyer advertising by supermarkets in the Netherlands', BMC Public Health, 15(1), pp. 1-10. Academic Search Complete, EBSCOhost [Online]. (Accessed: 7 April 2018).

Research, A.M. (2015) Research and markets: United Kingdom cooking \& eating habits market report 2015. Business Wire (English),

Rudi, J. and Çakır, M. (2017) 'Vice or virtue: how shopping frequency affects healthfulness of food choices', Food Policy, 69, pp. 207-217. doi: 10.1016/j.foodpol.2017.04.007. (Accessed: 6 February 2018).

Sandberg, S. (2016) '20/20 Grocery retailing - the shopper', Watt International Blog, 13 December 2016 [Online]. Available at: https://www.wattisretail.com/20-20-grocery-retailingthe-shopper/ (Accessed: 19 March 2018).

Skrovan, S. (2017) 'The state of the grocery shopper in 2017', Retail Dive, 11 January 2017 [Online]. Available at:

https://www.retaildive.com/news/the-state-of-the-grocery-shopper-in-2017/433815/ (Accessed: 28 April 2018).

Smith, G. (2018) 'Call to ban all confectionery price promos and set sugar tax at 20 per cent', New Food, 29 January 2018 [Online]. Available at:

https://www.newfoodmagazine.com/news/64249/call-ban-confectionery-price-promos-bringsugar-tax-20-per-cent/ (Accessed: 19 February 2018).

Sparks, L. and Burt, S. (2016) 'Identifying and understanding the factors that can transform the retail environment to enable healthier purchasing by consumers', Available at:

http://www.foodstandards.gov.scot/downloads/Research Findings.pdf (Accessed: 2 March 2018).

Statista (2018a) 'Distribution of Facebook users in the United Kingdom (UK) in January 2018, by age group'. Available at:

https://www.statista.com/statistics/507422/distribution-of-facebook-users-in-the-unitedkingdom-uk-by-age-group/ (Accessed: 3 April 2018).

Statista (2018) 'Distribution of Twitter users in the United Kingdom (UK) from 2012 to 2018, by age group'. Available at:

https://www.statista.com/statistics/271350/twitter-users-in-the-united-kingdom-uk/ (Accessed: 27 April 2018).

Statista (2014) 'Confectionery 'sharing bags' consumption habits in Great Britain 2014', Available at:

https://www.statista.com/statistics/319449/confectionery--sharing-bags--consumption-habitsin-great-britain/ (Accessed: 10 April 2018).

Stead, M., MacKintosh, A.M., Findlay, A., Sparks, L., Anderson, A.S., Barton, K. and Eadie, D. (2017) 'Impact of a targeted direct marketing price promotion intervention (Buywell) on food-purchasing behaviour by low income consumers: a randomised controlled trial', Journal of Human Nutrition and Dietetics, 30(4), 524-533. doi: 10.1111/jhn.12441. (Accessed: 15 April 2018). 
Stones, M. (2013) 'Promotions fuel obesity and waste', Food Manufacture, 88(12), p. 8. Business Source Complete, EBSCOhost [Online]. (Accessed: 21 February 2018).

Sun, B., Neslin, S.A. and Srinivassan, K. (2003) 'Measuring the impact of promotions on brand switching when consumers are forward looking', Journal of Marketing Research, 40(4), pp. 389-405. Business Source Complete, EBSCOhost [Online]. (Accessed: 21 February 2018).

Tey, S.L., Brown, R.C., Gray, A.R., Chisholm, A.W. and Delahunty, C.M. (2012) 'Long-term consumption of high energy-dense snack foods on sensory-specific satiety and intake', American Journal of Clinical Nutrition, 95(5), pp. 1038-1038-1047. doi: 10.3945/ajcn.111.030882. (Accessed: 15 April 2018).

Van Kleef, E., Otten, K. and van Trijp, H.C. (2012) 'Healthy snacks at the checkout counter: a lab and field study on the impact of shelf arrangement and assortment structure on consumer choices', BMC Public Health, 12(1), pp. 1-10. Academic Search Complete, EBSCOhost [Online]. (Accessed: 15 April 2018).

Vandevijvere, S., Waterlander, W., Molloy, J., Nattrass, H. and Swinburn, B. (2018) 'Towards healthier supermarkets: a national study of in-store food availability, prominence and promotions in New Zealand', European Journal of Clinical Nutrition, 72(7), pp. 971-978. doi: 10.1038/s41430-017-0078-6. (Accessed: 20 December 2019).

Wilson, J. (2016) 'Chocolate confectionery - Ireland - October 2016', Mintel reports platform, Irish series [Online]. (Accessed: 21 February 2018).

Winkler, L.L., Christensen, U., Glumer, C., Bloch, P., Mikkelsen, B.E., Wansink, B. and Toft, U. (2016) 'Substituting sugar confectionery with fruit and healthy snacks at checkout - a winwin strategy for consumers and food stores? A study on consumer attitudes and sales effects of a healthy supermarket intervention', BMC Public Health, 16 (1), pp. 1-12. Available at: https://doaj.org/article/3a5317cf88e84e7d90faf45a4dddc9e1. (Accessed: 21 February 2018).

Woodfield, J. (2018) 'Ban called for chocolate price promotions in bid to curb obesity'. Available at: https://www.diabetes.co.uk/news/2018/jan/ban-called-for-chocolate-pricepromotions-in-bid-to-curb-obesity-92439037.html (Accessed: 2 March 2018).

Wright, K.B. (2005) 'Researching Internet-based populations: advantages and disadvantages of online survey research, online questionnaire authoring software packages, and web survey services', Journal of Computer-Mediated Communication, 10(3). Available at: https://academic.oup.com/jcmc/article/10/3/JCMC1034/4614509. (Accessed: 2 March 2018).

Wynne-Jones, S. (2015) 'Consumers given opportunity to trade down', Checkout, 41(5), p.79. Business Source Complete, EBSCOhost [Online]. (Accessed: 21 February 2018).

Yan, J., Tian, K., Heravi, S. and Morgan, P. (2017) 'The vices and virtues of consumption choices: price promotion and consumer decision making', Marketing Letters, 28(3), pp. 461475. Business Source Complete, EBSCOhost [Online]. (Accessed: 2 March 2018). 